\title{
Preparation of Two Maleic Acid Sulfonamide Salts and Their Copper(II) Complexes and Antiglaucoma Activity Studies
}

\author{
Cengiz Yenikaya, ${ }^{*, a}$ Halil Ilkimen, ${ }^{a}$ Mehmet Melih Demirel, ${ }^{a}$ Burçin Ceyhan, ${ }^{a}$ \\ Metin Bülbüil ${ }^{b}$ and Ekrem Tunca ${ }^{b}$
} ${ }^{a}$ Department of Chemistry and ${ }^{b}$ Department of Biochemistry, Faculty of Arts and Sciences,
Dumlupınar University, 43100 Kütahya, Turkey

\begin{abstract}
Two novel proton transfer compounds $(\mathrm{HAP})^{+}(\mathrm{SAMAL})^{-}$and $(\mathrm{HBI})^{+}(\mathrm{SAMAL})^{-} \cdot \mathrm{H}_{2} \mathrm{O}$ were obtained from (E)-4-oxo-4-(4-sulfamoylphenylamino)but-2-enoic acid (HSAMAL) and 2-aminopyridine (AP) or $1 H$-benzimidazole (BI), respectively. Copper(II) complexes of salts and of HSAMAL have also been prepared. They have been characterized by elemental, spectral, thermal analyses, magnetic measurement and molar conductivity. Human carbonic anhydrase isozymes (hCA I and hCA II) were purified from erythrocytes by using affinity chromatography as 84.40 and 188.71 fold, respectively. The inhibitory effects of synthesized compounds and acetazolamide (AAZ, control compound) on the hydratase and esterase activities of hCA isozymes have been studied as in vitro to find out their antiglaucoma potentials. The inhibition constant $\left(\mathrm{K}_{\mathrm{i}}\right)$ values of the compounds were in the range of $0.18 \pm 0.007$ to $10.24 \pm 0.014 \mu \mathrm{mol} \mathrm{L}^{-1}$ for hCA I, and $0.12 \pm 0.004$ to $130.11 \pm 0.021 \mu \mathrm{mol} \mathrm{L}^{-1}$ for hCA II.
\end{abstract}

Keywords: (E)-4-oxo-4-(4-sulfamoylphenylamino)but-2-enoic acid, 2-aminopyridine, $1 H$-benzimidazole, proton transfer, carbonic anhydrase inhibition

\section{Introduction}

The sulfonamides constitute an important class of drugs, with several types of pharmacological agents possessing antibacterial, antiglaucoma, anti-inflammatory, protease inhibitors and antitumor activity, among others. ${ }^{1-3}$ Carbonic anhydrase (CA) is ubiquitous metalloenzyme that catalyze the two physiologically important processes: the first, the hydration of carbon dioxide to bicarbonate ion and a proton, and the second, the dehydration of bicarbonate ion. ${ }^{4-6}$ These simple reactions provide acid-base equilibrium and ion equilibrium, so carbonic anhydrases are involved in many physiological processes such as $\mathrm{pH}$ regulation, ion transport, electrolyte secretion, calcification, and some biosynthetic reactions. ${ }^{4,7}$ Among the mammalian carbonic anhydrases, $\alpha$-carbonic anhydrases, sixteen different $C A$ isoforms are expressed in humans. ${ }^{5,6}$ Human carbonic anhydrase (hCA) II isozyme which is present on the human eye $^{8}$ interacts with some membrane transport proteins, including chloride/bicarbonate exchanger, sodium/proton exchanger, and the sodium bicarbonate cotransporter. ${ }^{9}$ Thus hCA II plays a key role in the production of aqueous

*e-mail: cengiz.yenikaya@dpu.edu.tr humor. ${ }^{8}$ As a result, elevation in intraocular pressure (IOP) causes gradual loss of visual field called as glaucoma. ${ }^{10-12}$ One of the methods used in glaucoma treatment is to reduce the production of aqueous humor ${ }^{10,13}$ by using carbonic anhydrase inhibitors. ${ }^{4,5,11,13,14}$

2-Aminopyridines and benzimidazoles serve as useful chelating ligands in a variety of inorganic and organometallic applications, ${ }^{15-17}$ and also act as monodentate ligands which coordinate the metal ions through the nitrogen of the ring $^{16-21}$ in most cases. In addition, there are several works on 2-aminopyridine complexes in which the amino group also participates in coordination. ${ }^{22,23}$

The chemistry of copper(II) carboxylate complexes with $\mathrm{N}$-donor ligands especially with AP (2-animopyridine, 5) and BI $(1 H$-benzimidazole, 8 ) has been extensively studied over the past few decades. ${ }^{16,18-21}$ Two types of ligands, generally acids (e.g., carboxylic acids) and bases, e.g., $\mathrm{AP}$ or $\mathrm{BI}$, are brought together before coordination to the metal ion in order to prepare the mixed ligand complex compounds. ${ }^{18,24-26}$ The metal complexes with mixed ligands have shown better biological activities than the simple ones. ${ }^{18,19,27,28}$

In this study, two novel proton transfer compounds $(\mathrm{HAP})^{+}\left(\mathrm{SAMAL}^{-}(\mathbf{6})\right.$ and $(\mathrm{HBI})^{+}(\mathrm{SAMAL})^{-} \cdot \mathrm{H}_{2} \mathrm{O}(\mathbf{9})$, 
obtained from the acid 3 [HSAMAL, (E)-4-oxo-4-(4sulfamoylphenylamino)but-2-enoic acid] ${ }^{29}$ and the bases 5 or $\mathbf{8}$ ( $1 H$-benzimidazole), respectively, had their copper(II) complexes $7\left(\mathrm{C}_{20} \mathrm{H}_{22} \mathrm{~N}_{6} \mathrm{O}_{6} \mathrm{SCu}\right), \mathbf{1 0}\left(\mathrm{C}_{24} \mathrm{H}_{28} \mathrm{~N}_{6} \mathrm{O}_{10} \mathrm{SCu}_{2}\right)$ and $4\left(\mathrm{C}_{20} \mathrm{H}_{22} \mathrm{~N}_{4} \mathrm{O}_{12} \mathrm{~S}_{2} \mathrm{Cu}\right)$ prepared and characterized by nuclear magnetic resonance (NMR) of ${ }^{1} \mathrm{H}$ and ${ }^{13} \mathrm{C}$, Fourier transform infrared (FTIR), ultraviolet-visible (UV-Vis) spectroscopy, elemental and thermal analyses, magnetic measurement and molar conductivity.

\section{Experimental}

\section{Materials}

All reagents were of the highest grade commercially available and used without further purification. Elemental analyses for $\mathrm{C}, \mathrm{H}, \mathrm{N}$ and $\mathrm{S}$ were performed on Elementar Vario III EL (Hanau, Germany) and $\mathrm{Cu}$ was detected with PerkinElmer Optima 4300 DV ICP-OES (Wellesley, USA). ${ }^{1} \mathrm{H}$ NMR spectra were recorded with Bruker DPX FT NMR (500 MHz) spectrometer (Karlsruhe, Germany) with $\mathrm{SiMe}_{4}$ as internal standard and $85 \% \mathrm{H}_{3} \mathrm{PO}_{4}$ as an external standard. FTIR spectra were recorded in the $4000-400 \mathrm{~cm}^{-1}$ region with Bruker Optics, Vertex 70 FTIR spectrometer (Ettlingen, Germany) using ATR techniques. Thermal analyses were performed on SII Exstar 6000 TG/ DTA 6300 model (Shimadzu Corp., Kyoto, Japan) using platinum crucible with $10 \mathrm{mg}$ sample. Measurements were taken in the static air within a $30-900^{\circ} \mathrm{C}$ temperature range. The UV-Vis spectra were obtained for aqueous solutions of the compounds $\left(10^{3} \mathrm{M}\right)$ with a Shimadzu UV-2550 spectrometer (Kyoto, Japan) in the range of 200-900 nm. Magnetic susceptibility measurements at room temperature were performed using a Sherwood Scientific Magway MSB MK1 (Cambridge, UK) model magnetic balance by the Gouy method using $\mathrm{Hg}\left[\mathrm{Co}(\mathrm{SCN})_{4}\right]$ as calibrant. The molar conductances of the compounds were determined in water/ethanol $(1: 1, \mathrm{v} / \mathrm{v})$ and DMSO $\left(10^{-3} \mathrm{~mol} \mathrm{~L}^{-1}\right)$ at room temperature using a WTW Cond 315i/SET Model conductivity meter (Weilheim, Germany).

Synthesis of proton transfer salts (6 and 9) and metal complexes (4, 7 and 10)

The starting compound $\mathbf{3}$, the acid, was synthesized according to the literature. ${ }^{29}{ }^{1} \mathrm{H}$ NMR and ${ }^{13} \mathrm{C}$ NMR of the compound are given in Table 1 and other spectroscopic data can be found in Tables S1 and S2, Figures S1 and S2 at Supplementary Information.

A solution of 3 (1.351 g, $5 \mathrm{mmol})$ in $25 \mathrm{~mL}$ ethanol was added to $5 \mathrm{mmol}$ amine solution of $5(0.471 \mathrm{~g})$ for $\mathbf{6}$; or $8(0.591 \mathrm{~g})$ for 9 in $25 \mathrm{~mL}$ ethanol. The mixture was refluxed for $3 \mathrm{~h}$ and then was cooled to room temperature to give white solid of $\mathbf{6}$ or $\mathbf{9}$ (1.640 g, 90\% yield for $\mathbf{6}$, $1.554 \mathrm{~g}, 80 \%$ yield for $\mathbf{9})$.

A solution of $1 \mathrm{mmol} \mathrm{Cu}\left(\mathrm{CH}_{3} \mathrm{COO}\right)_{2} \cdot \mathrm{H}_{2} \mathrm{O}(0.199 \mathrm{~g})$ in water $(10 \mathrm{~mL})$ was added drop wise to the solution of $1 \mathrm{mmol}$ of $3(0.270 \mathrm{~g})$ for 4 ; or $6(0.364 \mathrm{~g})$ for 7 ; or $5(0.388 \mathrm{~g})$ for $10 \mathrm{in}$ water/ethanol $(1: 1, \mathrm{v} / \mathrm{v})(20 \mathrm{~mL})$ with stirring for four days at room temperature to give blue amorphous solid for 4 (0.239 g, 75\% yield); or green amorphous solid for 7 (0.269 g, 50\% yield); or red amorphous solid for $\mathbf{1 0}$ (0.607 g, 75\% yield).

Anal. calcd. for $4\left(\mathrm{C}_{20} \mathrm{H}_{22} \mathrm{~N}_{4} \mathrm{O}_{12} \mathrm{~S}_{2} \mathrm{Cu}\right)$ : C 37.65, H 3.48, N 8.78, S 10.05, Cu 9.96\%; found: C 37.70, H 3.43, N 8.79, $\mathrm{S} \mathrm{10.15,} \mathrm{Cu} \mathrm{9.95 \% ;} \mathrm{for} 6\left(\mathrm{C}_{15} \mathrm{H}_{16} \mathrm{~N}_{4} \mathrm{O}_{5} \mathrm{~S}\right): \mathrm{C} 49.44, \mathrm{H} 4.43$, N, 15.38, S 8.80\%; found: C 49.40, H 4.45, N 15.40, $\mathrm{S} 8.85 \%$; for $7\left(\mathrm{C}_{20} \mathrm{H}_{22} \mathrm{~N}_{6} \mathrm{O}_{6} \mathrm{SCu}\right)$ : C 44.65, H 4.12, N 15.62, $\mathrm{S} 5.96, \mathrm{Cu} 11.81 \%$; found: C 44.65, H 4.15, N 15.65, S 5.90, $\mathrm{Cu} 11.60 \%$; for $9\left(\mathrm{C}_{17} \mathrm{H}_{16} \mathrm{~N}_{4} \mathrm{O}_{5} \mathrm{~S}\right)$ : C 52.57, H 4.15, N 14.43, $\mathrm{S} 8.26 \%$; found: C 52.57, H 4.15, N 14.45, S 8.30\%; for $10\left(\mathrm{C}_{24} \mathrm{H}_{28} \mathrm{~N}_{6} \mathrm{O}_{10} \mathrm{SCu}_{2}\right): \mathrm{C} 40.05, \mathrm{H} 3.92, \mathrm{~N} 11.68, \mathrm{~S} 4.46$, $\mathrm{Cu}$ 17.66\%; found: C 39.90, H 3.95, N 11.65, S 4.40, $\mathrm{Cu} 17.20 \%$.

In addition, simple metal complexes of 5 (12, $\left.\left[\mathrm{Cu}_{2}(\mathrm{Ac})_{4}(\mathrm{AP})_{2}\right]\right)^{30}$ and $\mathbf{8}\left(\mathbf{1 3},\left[\mathrm{Cu}_{2}(\mathrm{Ac})_{4}(\mathrm{BI})_{2}\right]\right)^{31}$ were synthesized according to the literature in order to compare the inhibition studies with 4, 6, 7, 9 and $\mathbf{1 0}$.

Purification of carbonic anhydrase I and II isoenzymes from human erythrocytes

Erythrocytes were purified from human blood. The blood samples were centrifuged at $1500 \mathrm{rpm}$ for $20 \mathrm{~min}$ and plasma was removed. Later, red cells were washed with isotonic solution $(0.9 \% \mathrm{NaCl})$, and the erythrocytes were hemolyzed with 1.5 volumes of ice-cold water. Cell membranes were removed by centrifugation at $4{ }^{\circ} \mathrm{C}, 20000 \mathrm{rpm}$ for $30 \mathrm{~min}$. The $\mathrm{pH}$ of hemolysate was adjusted to 8.7 with solid TRIS (tris(hydroxymethyl)aminomethane). The hemolysate was applied to affinity column (Sepharose ${ }^{\circledR} 4 \mathrm{~B}$-L-tyrosine$p$-aminobenzene sulfonamide) pre-equilibrated with $25.0 \mathrm{mM}$ TRIS-HCl/0.1 $\mathrm{M} \mathrm{Na}_{2} \mathrm{SO}_{4}$ ( $\mathrm{pH}$ 8.7). After extensive washing with a solution of $25.0 \mathrm{mM}$ TRIS-HCl/22.0 mM $\mathrm{Na}_{2} \mathrm{SO}_{4}$ ( $\mathrm{pH} 8.7$ ), the hCA I and hCA II isoenzymes were eluted with the solution of $1.0 \mathrm{M} \mathrm{NaCl} / 25.0 \mathrm{mM} \mathrm{Na}_{2} \mathrm{HPO}_{4}$ (pH 6.3) and 0.1 $\mathrm{M} \mathrm{NaCH}_{3} \mathrm{COO} / 0.5 \mathrm{M} \mathrm{NaClO}_{4}$ (pH 5.6), respectively. ${ }^{32}$ For quantitative protein determination, the Bradford method was used with bovine serum albumin as a standard. ${ }^{33}$ Also purity control of the isoenzymes was performed with SDS-PAGE after the purification. ${ }^{34}$ 
Table 1. ${ }^{1} \mathrm{H}$ NMR and ${ }^{13} \mathrm{C}$ NMR chemical shifts $(\delta)$ with coupling constants and assignments for compound $\mathbf{3}$

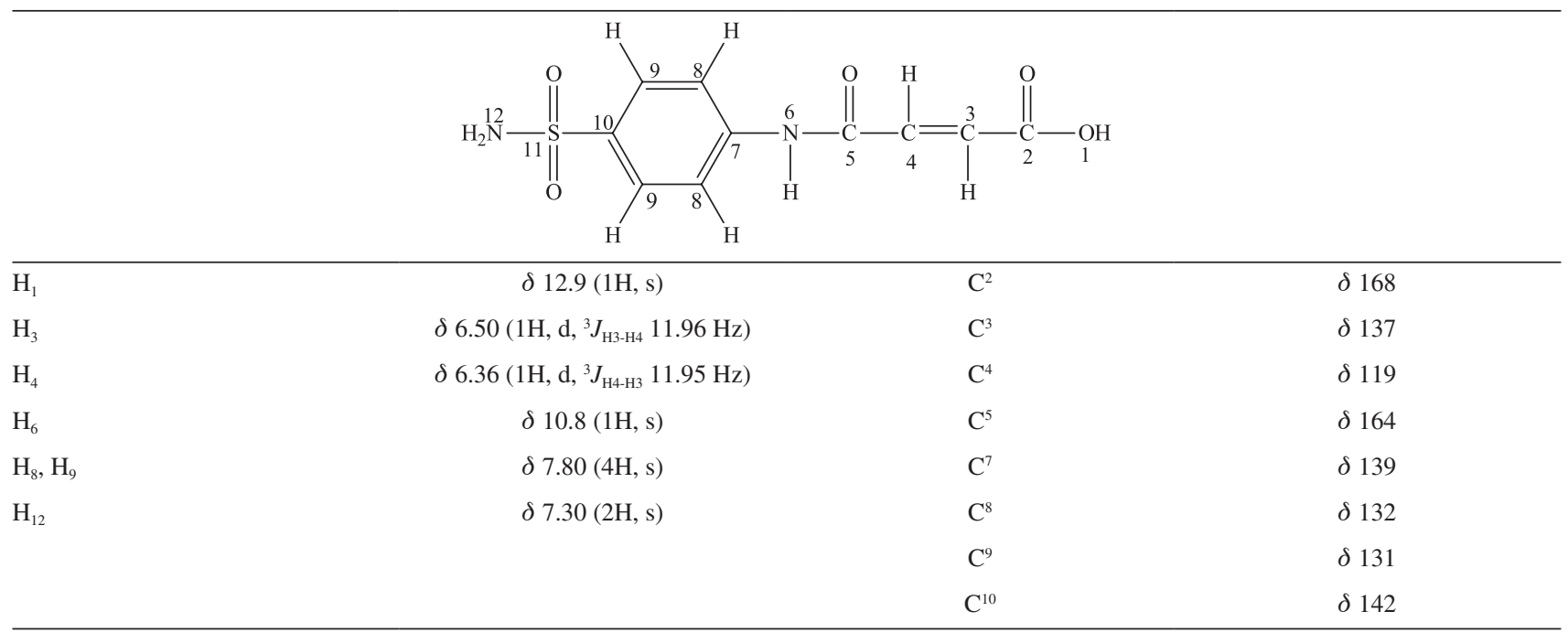

Determination of hydratase and esterase activities of hCA I and hCA II

The $\mathrm{CO}_{2}$ hydratase activity of the purified enzyme was determined at $0{ }^{\circ} \mathrm{C}$ in a veronal buffer $(\mathrm{pH}$ 8.15) with the $\mathrm{pH}$-stat method as the indicator and saturated carbon dioxide solution as the substrate in a final volume of $4.2 \mathrm{~mL}$. The time (in seconds) taken for the solution to change from $\mathrm{pH} 8.15$ to $\mathrm{pH} 6.50$ was measured. The enzyme unit (EU) is the enzyme amount that reduces the non-enzymatic reaction time by $50 \%$. The activity of an enzyme unit was calculated by using the equation $\left(\mathrm{t}_{0}-\mathrm{t}_{\mathrm{c}}\right) / \mathrm{t}_{\mathrm{c}}$, where $\mathrm{t}_{0}$ and $\mathrm{t}_{\mathrm{c}}$ are times for $\mathrm{pH}$ change of the non-enzymatic and enzymatic reactions, respectively. ${ }^{35}$

Esterase activity was assayed by following the change in the absorbance at $348 \mathrm{~nm}$ of 4-nitrophenylacetate to 4-nitrophenylate ion over a period of $3 \mathrm{~min}$ at $25^{\circ} \mathrm{C}$ using a spectrophotometer according to the method described in the literature. ${ }^{36}$ The enzymatic reaction, in a total volume of $3.0 \mathrm{~mL}$, contained $1.4 \mathrm{~mL}$ of $0.05 \mathrm{M}^{\text {TRIS- }} \mathrm{SO}_{4}$ buffer (pH 7.4), $1.0 \mathrm{~mL}$ of $3.0 \mathrm{mM}$ 4-nitrophenylacetate, $0.5 \mathrm{~mL}$ $\mathrm{H}_{2} \mathrm{O}$ and $0.1 \mathrm{~mL}$ enzyme solution. A reference measurement was obtained by preparing the same cuvette without enzyme solution.

\section{Determination of $\mathrm{IC}_{50}$ and $\mathrm{K}_{\mathrm{i}}$ values of the compounds}

To determine the $\mathrm{IC}_{50}$ values (the concentration of inhibitor producing a $50 \%$ inhibition of CA activity) of the simple ligands (4-aminobenzenesulfonamide (1), maleic anhydride (2), 5 and $\mathbf{8}$ ), proton transfer salt (6 and 9), metal complexes $(\mathbf{4}, \mathbf{7}$ and $\mathbf{1 0})$, and acetazolamide (AAZ, 11), as the control compound, hydratase and esterase activities of
CA isoenzymes were assayed in the presence of various inhibitor concentrations as mentioned above. Regression analysis graphs were drawn by plotting the percent enzyme activity $v s$. inhibitor concentration and $\mathrm{IC}_{50}$ values were calculated. ${ }^{24,26}$

To determine inhibition constant $\left(\mathrm{K}_{\mathrm{i}}\right)$ values as well as the inhibition type, three different inhibitor concentrations giving 30, 50 and $70 \%$ inhibition were selected. At each of these inhibitor concentrations, enzyme activity was measured in the presence of various substrate concentrations $(0.3,0.4,0.5,0.6$ and $0.7 \mathrm{mM})$ and the data were linearized with Lineweaver-Burk plot for $v_{\max }$ and the $\mathrm{K}_{\mathrm{i}}$ determination. Enzyme activity was also measured in the presence of the same substrate concentrations but in the absence of any inhibitor to determine the $v_{\max }{ }^{24,26}$

\section{Statistical analysis}

All the presented data were confirmed in at least three independent experiments and were expressed as the mean \pm standard deviation (SD). Data were analyzed by using a one-way analysis of variance for multiple comparisons (SPSS 13.0, SPSS Inc., Chicago, IL). $p<0.0001$ was considered to be statistically significant.

\section{Results and Discussion}

NMR studies of (HAP)+(SAMAL)- (6) and (HBI)+(SAMAL)-. $\mathrm{H}_{2} \mathrm{O}(9)$

The ${ }^{1} \mathrm{H}$ NMR and ${ }^{13} \mathrm{C}$ NMR spectra of the compounds for 6 and 9 were obtained in DMSO- $d_{6}$ with and without $\mathrm{D}_{2} \mathrm{O}$ at room temperature using TMS (tetramethylsilane) 
as internal standard (Figures S4-S7 at Supplementary Information). The ${ }^{1} \mathrm{H}$ signals were assigned on the basis of chemical shifts, multiplicities, intensities of the signals and coupling constants. Tables 2 and 3 lists complete ${ }^{1} \mathrm{H}$ NMR and ${ }^{13} \mathrm{C}$ NMR spectra of the compounds 6 and 9.

In ${ }^{1} \mathrm{H}$ NMR spectrum of 6 (Figure $\mathrm{S} 4 \mathrm{a}$, Table 2), the $\mathrm{H}^{3}$ and $\mathrm{H}^{4}$ protons of the $\mathbf{3}$ are doublets with $1 \mathrm{H}$ intensities and they are observed at $\delta 6.36\left(\mathrm{H}^{3},{ }^{3} J_{\mathrm{H} 3-\mathrm{H} 4} 12.14 \mathrm{~Hz}\right)$ and $6.33\left(\mathrm{H}^{4},{ }^{3} J_{\mathrm{H} 4-\mathrm{H} 3} 12.11 \mathrm{~Hz}\right.$, indicating trans position of $\mathrm{H}^{3}$ and $\mathrm{H}^{4}$ ). The symmetrical $\mathrm{H}^{8}$ and $\mathrm{H}^{9}$ protons of the benzene rings are singlet with $4 \mathrm{H}$ intensity (as in $\mathbf{3}$ ${ }^{1} \mathrm{H}$ NMR spectrum, Table 1 and Figure S1) and they are observed at $\delta 7.80$. The $\mathrm{H}^{15}$ and $\mathrm{H}^{18}$ protons of the (HAP) ${ }^{+}$ ring are doublet-doublet with $1 \mathrm{H}$ intensities and they are observed at $\delta 6.50\left(\mathrm{H}^{15},{ }^{3} J_{\mathrm{H} 15-16} 8.41 \mathrm{~Hz},{ }^{4} J_{\mathrm{H} 15-17} 2.84 \mathrm{~Hz}\right)$ and $7.90\left(\mathrm{H}^{18},{ }^{3} J_{\mathrm{H} 18-17} 5.07 \mathrm{~Hz},{ }^{4} J_{\mathrm{H} 18-16} 2.38 \mathrm{~Hz}\right)$. The $\mathrm{H}^{16}$ and $\mathrm{H}^{17}$ protons of the (HAP) ${ }^{+}$ring are triplet-doublet with $1 \mathrm{H}$ intensities and they are observed at $\delta 6.50$ $\left(\mathrm{H}^{16},{ }^{3} J_{\mathrm{H} 16-17,15} 8.72 \mathrm{~Hz},{ }^{4} J_{\mathrm{H} 16-18} 2.69 \mathrm{~Hz}\right)$ and 7.42 $\left({ }^{3} J_{\mathrm{H} 17-16,18} 7.20 \mathrm{~Hz},{ }^{4} J_{\mathrm{H} 17-15} 2.98 \mathrm{~Hz}\right)$. The $\mathrm{H}^{13}$ proton of the 6 was not observed in the ${ }^{1} \mathrm{H}$ NMR spectrum. The $\mathrm{H}^{6}, \mathrm{H}^{12}$ and $\mathrm{H}^{19}$ protons of the 6 are singlets as expected and arisen at $\delta 11.30$ with $1 \mathrm{H}$ intensity, $\delta 7.30$ with $2 \mathrm{H}$ intensity and $\delta 6.20$ with $2 \mathrm{H}$ intensity, respectively. These protons $\left(\mathrm{H}^{6}, \mathrm{H}^{12}, \mathrm{H}^{13}\right.$ and $\left.\mathrm{H}^{19}\right)$ were not observed in the ${ }^{1} \mathrm{H}$ NMR spectrum obtained in DMSO- $d_{6}$ with $\mathrm{D}_{2} \mathrm{O}$ due to deuterium exchange (Figure S4b).
In ${ }^{1} \mathrm{H}$ NMR spectrum of 9 (Figure S6a, Table 3), the $\mathrm{H}^{3}$ and $\mathrm{H}^{4}$ protons of the 3 are doublets with $1 \mathrm{H}$ intensities and they are observed at $\delta 6.49\left(\mathrm{H}^{3},{ }^{3} \mathrm{~J}_{\mathrm{H} 3-\mathrm{H} 4} 12.00 \mathrm{~Hz}\right)$ and 6.34 $\left(\mathrm{H}^{4},{ }^{3} \mathrm{~J}_{\mathrm{H} 4 \mathrm{H} 3} 11.90 \mathrm{~Hz}\right.$, indicating trans position of $\mathrm{H}^{3}$ and $\left.\mathrm{H}^{4}\right)$. The symmetrical $\mathrm{H}^{8}$ and $\mathrm{H}^{9}$ protons of the benzene rings are singlet with $4 \mathrm{H}$ intensity (as in $\mathbf{3}^{1} \mathrm{H}$ NMR spectrum, Table 1 and Figure S1) and they are observed at $\delta 7.80$. The symmetrical $\mathrm{H}^{16}$ and $\mathrm{H}^{17}$ protons of the (HBI) ${ }^{+}$ring are doublet-doublet with $2 \mathrm{H}$ intensities and they are observed at $\delta 7.60\left(\mathrm{H}^{16},{ }^{3} J_{\mathrm{H} 16-\mathrm{H} 17} 5.98 \mathrm{~Hz},{ }^{4} J_{\mathrm{H} 16-\mathrm{H} 17}, 2.99 \mathrm{~Hz}\right)$ and 7.20 $\left(\mathrm{H}^{17},{ }^{3} J_{\mathrm{H} 17-\mathrm{H} 16} 6.02 \mathrm{~Hz},{ }^{4} J_{\mathrm{H} 17-\mathrm{H} 16}, 2.86 \mathrm{~Hz}\right)$. The $\mathrm{H}^{14}$ and $\mathrm{H}^{18}$ proton of the 9 were not observed in the ${ }^{1} \mathrm{H}$ NMR spectrum (as in $\mathrm{BI}$ molecule due to tautomerism). The $\mathrm{H}^{6}, \mathrm{H}^{12}$ and $\mathrm{H}^{13}$ protons of the 9 are singlets as expected and arisen at $\delta 10.80$ with $1 \mathrm{H}$ intensity, 7.20 with $2 \mathrm{H}$ intensity and 8.20 with $1 \mathrm{H}$ intensity, respectively. These protons $\left(\mathrm{H}^{6}, \mathrm{H}^{12}\right.$, $\mathrm{H}^{13}$ and $\mathrm{H}^{19}$ ) were not observed in the $1 \mathrm{H}$ NMR spectrum obtained in DMSO- $d_{6}$ with $\mathrm{D}_{2} \mathrm{O}$ due to deuterium exchange (Figure S6b) although the hydrate water molecule $\left(\mathrm{H}^{19}\right)$ was observed in the thermal studies. For both compounds $\left(\mathbf{6}\right.$ and 9) the acidic hydrogen $\left(\mathrm{H}^{1}\right)$ were not observed due to the salt formation, although it was distinguishable in $\mathbf{3}$ ${ }^{1} \mathrm{H}$ NMR spectrum (Figures S1, S4, S6).

${ }^{13} \mathrm{C}$ NMR spectra of $\mathbf{6}$ and $\mathbf{9}$ exhibit thirteen and twelve resonances, respectively (Figures S5 and S7, Tables 2 and 3). Eight peaks out of these resonances $\delta 168$ $\left(\mathrm{C}^{2}\right), 127\left(\mathrm{C}^{3}\right), 119\left(\mathrm{C}^{4}\right)$ and $164\left(\mathrm{C}^{5}\right), 139\left(\mathrm{C}^{7}\right), 132\left(\mathrm{C}^{8}\right)$,

Table 2. ${ }^{1} \mathrm{H}$ NMR and ${ }^{13} \mathrm{C}$ NMR chemical shifts $(\delta)$ with coupling constants and assignments for compound 6

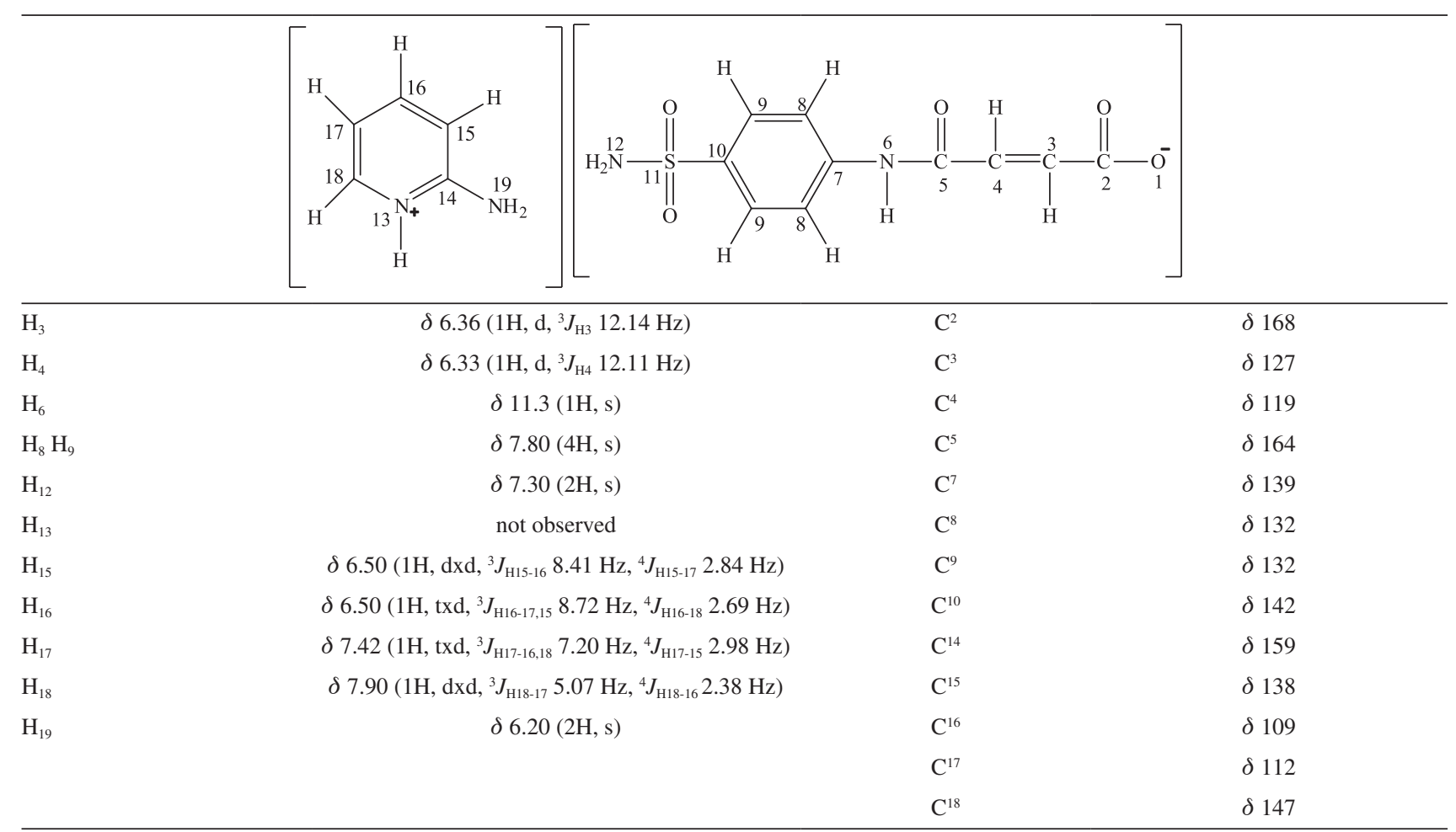


Table 3. ${ }^{1} \mathrm{H}$ NMR and ${ }^{13} \mathrm{C}$ NMR chemical shifts $(\delta)$ with coupling constants and assignments for compound 9

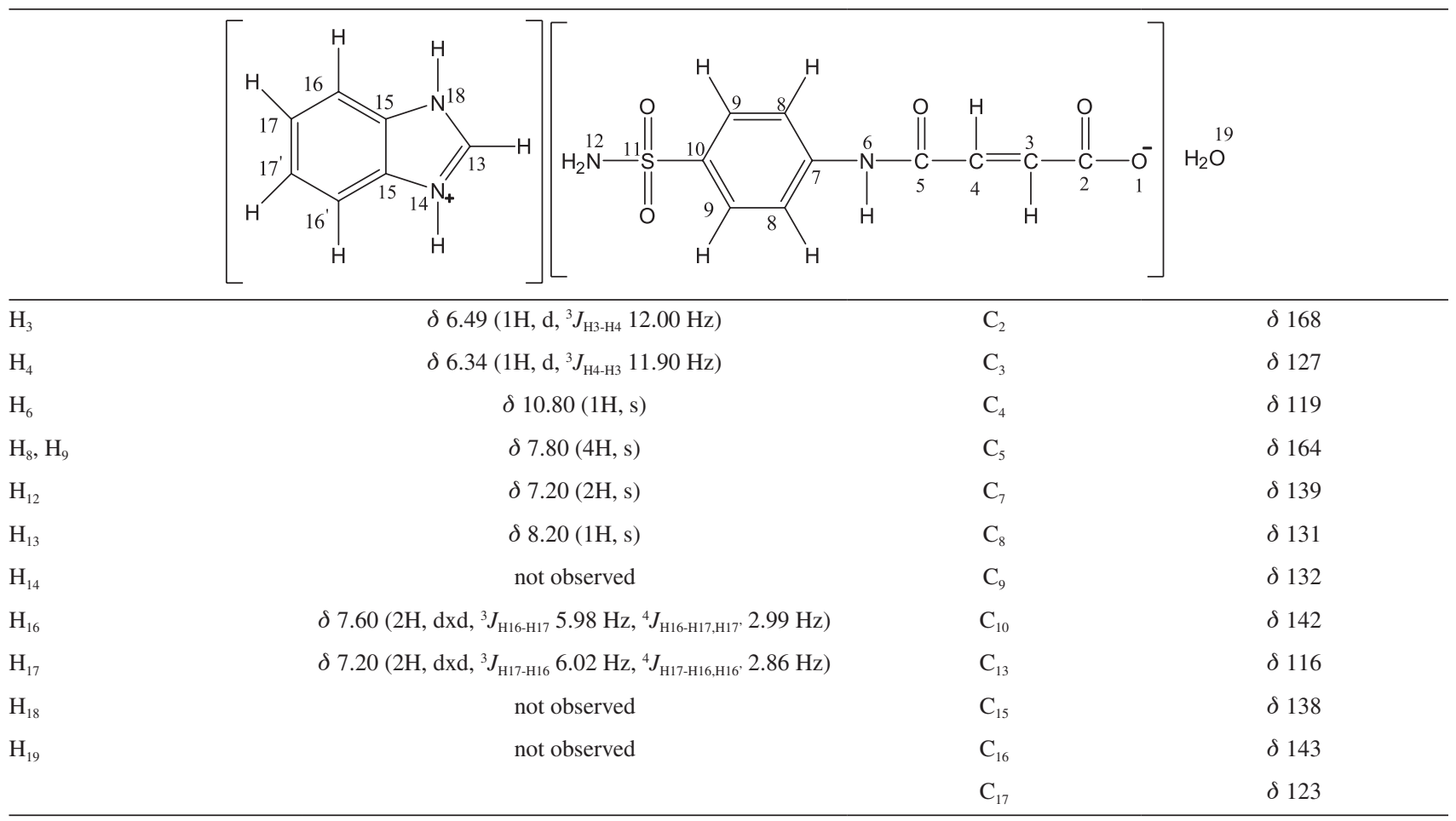

$131\left(\mathrm{C}^{9}\right)$ and $142\left(\mathrm{C}^{10}\right)$ could be assigned to the carbons of $\mathrm{SAMAL}^{-}$group of all compunds moiety. Five peaks for 6 at $\delta 159\left(\mathrm{C}^{14}\right), 138\left(\mathrm{C}^{15}\right), 109\left(\mathrm{C}^{16}\right), 112\left(\mathrm{C}^{17}\right)$ and $147\left(\mathrm{C}^{18}\right)$ could be assigned to the carbons of (HAP) $)^{+}$ring moiety. Four peaks for 9 at $\delta 116\left(\mathrm{C}^{13}\right), 138\left(\mathrm{C}^{15}\right), 143\left(\mathrm{C}^{16}\right)$ and $123\left(\mathrm{C}^{17}\right)$ could be assigned to the carbons of $(\mathrm{HBI})^{+}$ring of moiety.

The room temperature NMR spectra for compounds 6 and 9 indicate clearly the formation of the proton transfer compounds between $\mathbf{3}$ and $\mathbf{5}$ or $\mathbf{8}$ with 1:1 ratio (Figure 1).

\section{FTIR measurements}

The infrared spectral data of the starting compounds $\mathbf{3}$, 5 and 8 ) and compounds 4, 6, 7, 9, 10 are given in Table S1. In the high frequency region, weak bands 3013-2854 and $3120-3069 \mathrm{~cm}^{-1}$ are attributed to the stretching vibrations of aromatic $\mathrm{C}-\mathrm{H}$. There is a broad absorption band at $2900 \mathrm{~cm}^{-1}$ attributed to the $\mathrm{v}(\mathrm{OH})$ vibrations of carboxylate group of HSAMAL. This band is not observed in compounds 6 and 9 due to proton transfer to AP or BI and in $\mathbf{4}$ due to complex formation. There are also broad absorption bands at $3484-3390 \mathrm{~cm}^{-1}$ which are attributed to the $v(\mathrm{OH})$ vibrations of coordinated and uncoordinated water and hydroxide moieties in the compounds 4, 7,9 and 10. The relatively weak and broad band at $2757-2549 \mathrm{~cm}^{-1}$ is attributed to the $v\left(\mathrm{~N}^{+}-\mathrm{H}\right)$ vibration for 6 from $(\mathrm{HAP})^{+}$ and for 9 from $(\mathrm{HBI})^{+}$indicating the salt formation. These bands were not observed for the compounds $\mathbf{7}$ and $\mathbf{1 0}$ due to the deprotonation of the salt during the complex formation (Figure 1). $\mathrm{NH}_{2}$ vibrations of sulfonamides in free HSAMAL (3352 and $\left.3212 \mathrm{~cm}^{-1}\right)$, in $4(3355,3306$ and $3240 \mathrm{~cm}^{-1}$ ), in 6 (3432 and $\left.3303 \mathrm{~cm}^{-1}\right)$, in 7 (3351 and $\left.3232 \mathrm{~cm}^{-1}\right)$, in $9\left(3365,3322\right.$ and $\left.3266 \mathrm{~cm}^{-1}\right)$ and in $\mathbf{1 0}$ (3312 and $3103 \mathrm{~cm}^{-1}$ ) are observed with similar pattern. The strong $\mathrm{C}=\mathrm{O}$ vibration at 1695 and $1630 \mathrm{~cm}^{-1}$ of HSAMAL are shifted to 1691 and $1654 \mathrm{~cm}^{-1}$ for compounds 4,1677 and $1633 \mathrm{~cm}^{-1}$ for compound $\mathbf{6}, 1692$ and $1659 \mathrm{~cm}^{-1}$ for compound 7, 1668 and $1626 \mathrm{~cm}^{-1}$ for compound 9 and 1668 and $1602 \mathrm{~cm}^{-1}$ for compound 10. It indicates the role of carboxylic acid on the structures of 4, 6, 7, 9 and carboxylic acid and amid groups on the structure of $\mathbf{1 0}$. The strong absorption bands at the region of 1626-1408 $\mathrm{cm}^{-1}$ are attributed to the $v(C=N)$ and $v(C=C)$ vibrations for all compounds. In the latter case, SAMAL- was assumed to coordinate to the copper(II) ion from both carbonyl groups. The strong absorption bands for $\mathrm{SO}_{2}$ groups in HSAMAL in compounds $\mathbf{4 , 7}$ and $\mathbf{1 0}$ are observed at the region of $1409-1091 \mathrm{~cm}^{-1}$ with similar profiles and almost similar vibrations. The ring wagging vibrations of the pyridine groups are also observed at 768-731 $\mathrm{cm}^{-1}$ region for compounds AP and 6 and 7. The weak bands at $537-555 \mathrm{~cm}^{-1}$ and $476-438 \mathrm{~cm}^{-1}$ are from the $\mathrm{M}-\mathrm{N}$ and M-O vibrations of compounds 4, 7 and $\mathbf{1 0 .}$ 

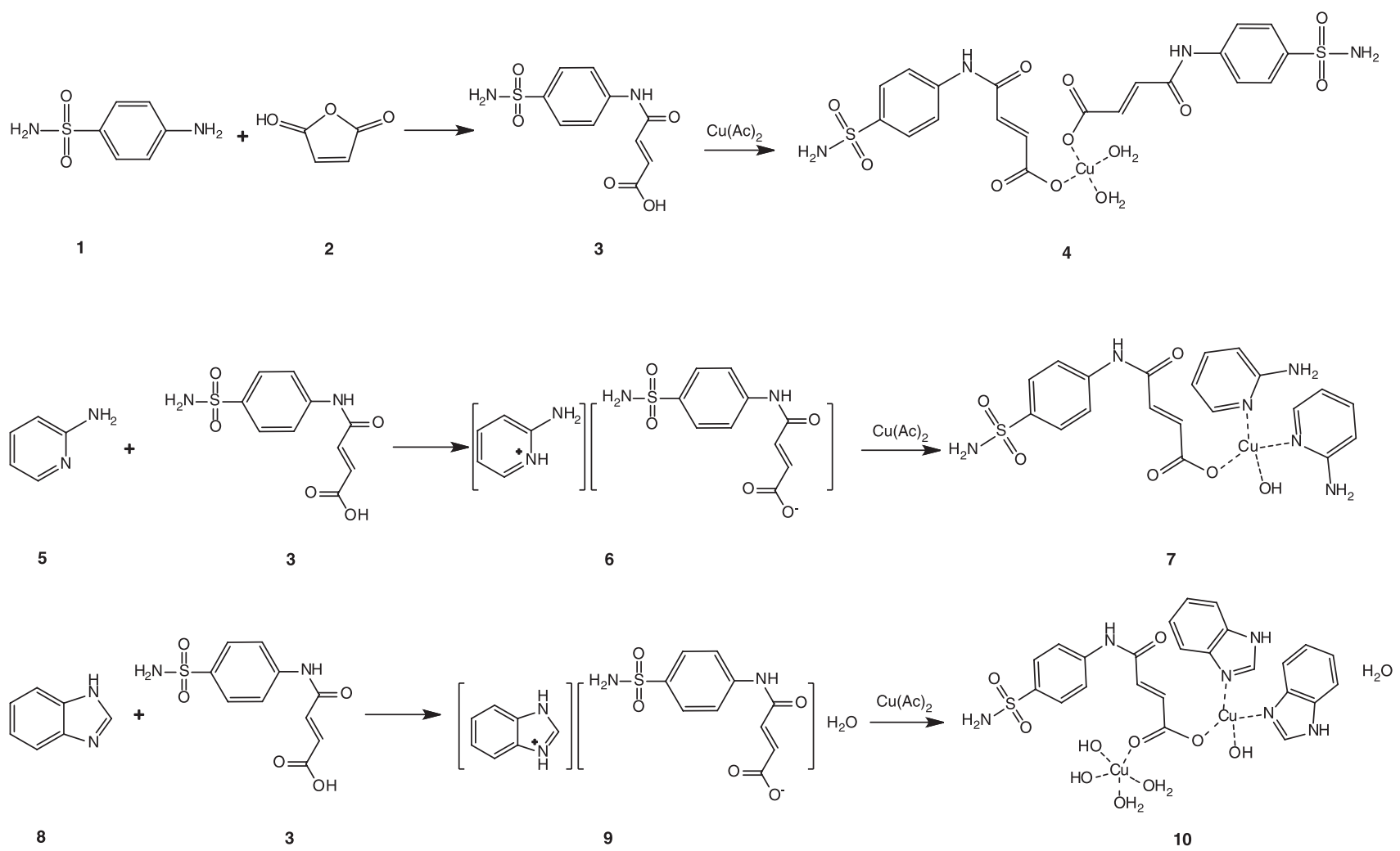

Figure 1. Syntheses of compounds 3, 4, 6, 7, 9 and 10 .

Thermal analyses of 4, 6, 7, 9 and 10

Figures S8-S12 show the TG-DTG and DTA curves of compounds 4, 6, 7, 9 and 10 and the thermal analyses results are given in Table $\mathbf{S} 2$.

For the compound 6, two stages are observed and the first endothermic stage corresponds to the loss of $\mathrm{C}_{5} \mathrm{H}_{9} \mathrm{~N}_{3} \mathrm{O}_{2} \mathrm{~S}$ (possibly HAP $+\mathrm{SO}_{2} \mathrm{NH}_{2}$ ) unit and the second exothermic one is the decomposition of the residue of $\mathrm{C}_{10} \mathrm{H}_{7} \mathrm{NO}_{3}$ unit (possibly $\mathrm{C}_{6} \mathrm{H}_{4} \mathrm{NHCOCHCHCOO}$ ).

For the compound $\mathbf{7}$, three stages are observed. The first endothermic peak corresponds to the loss of one mole $\mathrm{OH}$. The second endothermic stage is consistent to the loss of two moles of AP. One mole of SAMAL is decomposed exothermically in the third stage. The final decomposition product is $\mathrm{CuO}$ identified by IR spectroscopy.

For the compound 9, three stages are observed, and the first endothermic stage corresponds to the loss of one mole of water. The second one is endothermic stage, which corresponds to the loss of $\mathrm{C}_{7} \mathrm{H}_{10} \mathrm{~N}_{3} \mathrm{O}_{2} \mathrm{~S}$ unit (possibly HBI $+\mathrm{SO}_{2} \mathrm{NH}_{2}$ ) and the third second exothermic one is the decomposition of the residue of $\mathrm{C}_{10} \mathrm{H}_{7} \mathrm{NO}_{3}$ unit (possibly $\mathrm{C}_{6} \mathrm{H}_{4} \mathrm{NHCOCHCHCOO}$ ).

For the compounds $\mathbf{4}$ and $\mathbf{1 0}$, three stages are observed, and the first endothermic stage corresponds to the loss of two coordinated water molecules for $\mathbf{4}$ and one uncoordinated water molecule for $\mathbf{1 0}$. The endothermic second stage is consistent to the loss of 2 moles sulfonamide $\left(\mathrm{SO}_{2} \mathrm{NH}_{2}\right)$ for 4 and $\mathrm{C}_{12} \mathrm{H}_{13} \mathrm{O}_{5}$ units (possibly $2 \mathrm{H}_{2} \mathrm{O}+3 \mathrm{OH}+2 \mathrm{C}_{6} \mathrm{H}_{3}$ ) for 10. $\mathrm{C}_{20} \mathrm{H}_{14} \mathrm{~N}_{2} \mathrm{O}_{6}$ (possibly $2 \mathrm{AP}+\mathrm{C}_{6} \mathrm{H}_{4} \mathrm{NHCOCHCHCOO}$ ) and $\mathrm{C}_{12} \mathrm{H}_{13} \mathrm{~N}_{6} \mathrm{O}_{5} \mathrm{~S}$ units (possibly SAMAL $+2 \mathrm{CH}_{2} \mathrm{~N}_{2}$ ) are also decomposed exothermically in the following stage for 4 and 10, respectively. The final decomposition products are $\mathrm{CuO}$ for $\mathbf{4}$ and $\mathbf{1 0}$ and they are identified by IR spectroscopy.

UV-Vis spectrum, magnetic susceptibility and molar conductivity

The electronic spectra of compounds 4, 6, 7,9 and 10 and the free ligands $\mathbf{3}, \mathbf{5}$ and $\mathbf{8}$ were recorded in DMSO solution with $1 \times 10^{-3} \mathrm{~mol} \mathrm{~L}^{-1}$ concentrations at room temperature (Table S3). Characteristic $\pi-\pi *$ transitions in the range of 283-367 nm (2500-48170 $\left.\mathrm{L} \mathrm{mol}^{-1} \mathrm{~cm}^{-1}\right)$ for 4, 6, 7, 9 and 10 are observed in DMSO. The same $\pi-\pi^{*}$ transition profiles are also detected for the free ligands HSAMAL, AP and BI and there is no marked difference from those of either proton transfer compounds or metal complexes. The bands for the d-d transitions in DMSO are observed at $765 \mathrm{~nm}\left(150 \mathrm{~L} \mathrm{~mol}^{-1} \mathrm{~cm}^{-1}\right)$ for $4,761 \mathrm{~nm}$ (200 $\left.\mathrm{L} \mathrm{mol}^{-1} \mathrm{~cm}^{-1}\right)$ for 7, $769 \mathrm{~nm}\left(240 \mathrm{~L} \mathrm{~mol}^{-1} \mathrm{~cm}^{-1}\right)$ for 10 .

The room temperature magnetic moments of the metal complexes are 1.65 BM for 4, 1.67 BM for 7 and $1.69 \mathrm{BM}$ 
for $\mathbf{1 0}$ per metal ion, indicating the presence of one $\left(d^{9}\right)$ unpaired electron and absence of metal-metal bond for $\mathbf{1 0}$.

The molar conductivity data in DMSO are $3.8 \Omega^{-1} \mathrm{~cm}^{2} \mathrm{~mol}^{-1}$ for $4,3.0 \Omega^{-1} \mathrm{~cm}^{2} \mathrm{~mol}^{-1}$ for 7 and $1.8 \Omega^{-1} \mathrm{~cm}^{2} \mathrm{~mol}^{-1}$ for 10 indicating that the complexes 4,7 and $\mathbf{1 0}$ are non-ionic ${ }^{37}$ and $\mathrm{OH}^{-}$groups are coordinated to the copper(II) ions.

The very powerful tool single $\mathrm{X}$-ray diffraction studies cannot be applied to identify the structures of complexes 4, 7 and $\mathbf{1 0}$ due to their powdery forms. Using elemental and thermal analyses, the formulas of the complexes were proposed with the aid of spectral (FTIR, UV-Vis) and of magnetic susceptibility and molar conductivity studies (Figure 1).

\section{CA purification and inhibition assay}

For achievement of the purpose of the study, hCA I and hCA II isozymes were purified from human erythrocytes and the inhibition potentials of proton transfer salt, simple metal complexes and mixed ligand complexes have been tested on these isozymes. Specific activity was calculated for purified hCA I and II (918.4 EU mg-1 for hCA I and $2053.2 \mathrm{EU} \mathrm{mg}^{-1}$ for hCA II). hCA I and hCA II isozymes were purified from erythrocytes as 84.40 and 188.71 fold, respectively (Table $\mathrm{S} 4$ ).

Newly synthesized proton transfer salt and mixed ligand complexes, as well as the reference compound AAZ were tested under in vitro conditions for their inhibition potentials against hCA I and hCA II (Table 4).
Simple ligands, $\mathbf{5}$ and $\mathbf{8}$, and simple metal complexes, $\mathbf{1 2}$ and 13, did not inhibit the hydratase and esterase activities of hCA I and hCA II isozymes.

The slow cytosolic isoform, hCA I, was moderately inhibited by synthesized compounds for hydratase activity. Compounds 4, 6, 7, 9 and 10 have weaker inhibition potentials than AAZ. Among the synthesized compounds, the complex $\mathbf{4}$ has most powerful inhibition effect on the hydratase activity of hCA I $\left(\mathrm{IC}_{50}\right.$ values $13.34 \mu \mathrm{M}$, Table 4$)$. Unlike the hydratase activity, 3 and compounds 4, 6, 7,9 and $\mathbf{1 0}$ have comparable inhibition potential with AAZ for esterase activity. Generally, proton transfer salts and mixed ligand complexes have stronger inhibition effects than simple ligands and simple metal complexes on the esterase activity of hCA I. Regarding to $\mathrm{K}_{\mathrm{i}}$ values, it is shown that the proton transfer salt (6) and its metal complex (7) are stronger inhibitor than the other proton transfer salt (9) and its metal complex (10) (Table 4). For esterase activity of hCA I, $\mathbf{6}$ has shown the highest inhibition effect (esterase $\mathrm{IC}_{50}$ value $0.57 \pm 0.002 \mu \mathrm{mol} \mathrm{L} \mathrm{L}^{-1}$ and $\mathrm{K}_{\mathrm{i}}$ value $\left.0.18 \pm 0.007 \mu \mathrm{mol} \mathrm{L}^{-1}\right)$. Inhibition potentials were in the order of AAZ $>6>7 \approx 9>10>4>3$ according to esterase $\mathrm{IC}_{50}$ values, and $\mathbf{6}>\mathrm{AAZ}>\mathbf{7}>\mathbf{9}>\mathbf{1 0} \approx \mathbf{4}>\mathbf{3}$ according to $\mathrm{K}_{\mathrm{i}}$ values.

Similar to hCA I, the faster and physiologically dominant isoform hCA II was moderately inhibited by synthesized compounds for hydratase activity. However inhibition effects of synthesized compounds are higher for the hydratase activity of hCA II than the hydratase activity of hCA I. As seen from Table 4, the inhibition potentials of compounds

Table 4. The inhibition data and $\mathrm{K}_{\mathrm{i}}$ values of hCA I and hCA II isozymes for hydratase and esterase activity

\begin{tabular}{|c|c|c|c|c|c|c|}
\hline \multirow{2}{*}{ Compound } & \multicolumn{2}{|c|}{ Hydratase $\mathrm{IC}_{50} \mathrm{~b}, \mathrm{c} /\left(\mu \mathrm{mol} \mathrm{L}{ }^{-1}\right)$} & \multicolumn{2}{|c|}{ Esterase $\mathrm{IC}_{50} \mathrm{~b}, \mathrm{c} /\left(\mu \mathrm{mol} \mathrm{L}{ }^{-1}\right)$} & \multicolumn{2}{|c|}{$\mathrm{K}_{\mathrm{i}}^{\mathrm{b}, \mathrm{c}} /\left(\mu \mathrm{mol} \mathrm{L}{ }^{-1}\right)$} \\
\hline & hCA I & hCA II & hCA I & hCA II & hCA I & hCA II \\
\hline $\mathrm{AAZ}$ & $0.39 \pm 0.008$ & $0.20 \pm 0.005$ & $0.42 \pm 0.004$ & $0.31 \pm 0.008$ & $0.26 \pm 0.003$ & $0.14 \pm 0.005$ \\
\hline 1 & $30.44 \pm 0.008$ & $5.67 \pm 0.003$ & $28.14 \pm 0.012$ & $5.36 \pm 0.005$ & $26.32 \pm 0.009$ & $4.14 \pm 0.011$ \\
\hline 2 & no inhibition & no inhibition & no inhibition & no inhibition & no inhibition & no inhibition \\
\hline 3 & $84.07 \pm 0.012$ & $56.48 \pm 0.009$ & $1.64 \pm 0.005$ & $1.51 \pm 0.009$ & $1.02 \pm 0.004$ & $0.93 \pm 0.006$ \\
\hline 4 & $13.34 \pm 0.005$ & $10.58 \pm 0.008$ & $1.43 \pm 0.007$ & $1.03 \pm 0.006$ & $0.98 \pm 0.013$ & $0.91 \pm 0.003$ \\
\hline 5 & no inhibition & no inhibition & no inhibition & no inhibition & no inhibition & no inhibition \\
\hline 6 & $49.57 \pm 0.008$ & $28.40 \pm 0.007$ & $0.57 \pm 0.002$ & $0.42 \pm 0.011$ & $0.18 \pm 0.007$ & $0.13 \pm 0.008$ \\
\hline 7 & $21.76 \pm 0.009$ & $18.44 \pm 0.010$ & $0.80 \pm 0.003$ & $0.25 \pm 0.003$ & $0.30 \pm 0.005$ & $0.12 \pm 0.004$ \\
\hline 8 & no inhibition & no inhibition & no inhibition & no inhibition & no inhibition & no inhibition \\
\hline 9 & $50.87 \pm 0.010$ & $22.07 \pm 0.013$ & $0.81 \pm 0.003$ & $0.72 \pm 0.002$ & $0.56 \pm 0.004$ & $0.35 \pm 0.002$ \\
\hline 10 & $24.11 \pm 0.003$ & $23.01 \pm 0.006$ & $1.36 \pm 0.005$ & $1.19 \pm 0.008$ & $0.97 \pm 0.002$ & $0.86 \pm 0.001$ \\
\hline 12 & no inhibition & no inhibition & no inhibition & no inhibition & no inhibition & no inhibition \\
\hline 13 & no inhibition & no inhibition & no inhibition & no inhibition & no inhibition & no inhibition \\
\hline $\mathrm{Cu}(\mathrm{Ac})_{2} \cdot \mathrm{H}_{2} \mathrm{O}$ & $14.21 \pm 0.004$ & $145.71 \pm 0.028$ & $11.25 \pm 0.010$ & $141.13 \pm 0.024$ & $10.24 \pm 0.014$ & $130.11 \pm 0.021$ \\
\hline
\end{tabular}

aAZ was used as reference compound; ${ }^{\mathrm{a}}$ mean \pm standard error, from three different assays; ${ }^{\mathrm{c}} p<0.0001$ for all analysis. 
4, 6, 7, 9 and 10 are higher at least two-fold than simple ligand, 3. Similar to hCA I, $\mathbf{4}$ is the most potent inhibitor for the hydratase activity of hCA II $(10.58 \pm 0.008 \mu \mathrm{M}$, Table 4). Newly synthesized compounds exhibited similar effects to hCA I on esterase activity of this isoform. Compound 7 (esterase $\mathrm{IC}_{50}=0.25 \pm 0.003 \mu \mathrm{mol} \mathrm{L}^{-1}$ and $\mathrm{K}_{\mathrm{i}} 0.12 \pm 0.004 \mu \mathrm{mol} \mathrm{L}^{-1}$ for hCA II) have shown effective inhibition on the isozyme. When compared the inhibition effects of synthesized compounds, it is shown that $\mathbf{6}$ and $\mathbf{7}$ is more effective than others. AP and BI moieties in proton transfer salts and mixed ligand complexes have changed inhibition effects of compounds. But it is rather difficult to rationalize these data as no X-ray crystal structures of CA-inhibitor interactions. Inhibition potentials were in the order of $\mathbf{7}>\mathrm{AAZ}>\mathbf{6}>\mathbf{9}>\mathbf{4}>\mathbf{1 0}>\mathbf{3}$ according to esterase $\mathrm{IC}_{50}$ values, and $\mathbf{7} \approx \mathbf{6} \approx \mathrm{AAZ}>\mathbf{9}>\mathbf{1 0}>\mathbf{4}>\mathbf{3}$ according to $\mathrm{K}_{\mathrm{i}}$ values.

In summary, synthesized compounds have pharmacologically remarkable inhibition potentials on hCA I and hCA II. These compounds can be the candidate agents for further studies of glaucoma therapy.

\section{Conclusions}

In this present work, two novel proton transfer salts (6 and 9) of maleic acid sulfonamide, three copper(II) complexes $(4,7$ and 10$)$ were prepared for the first time. The formulas of $\mathbf{4 , 7}$ and $\mathbf{1 0}$ have been proposed by the results of elemental, spectral, magnetic measurement, molar conductivity and thermal analyses.

These newly synthesized proton transfer salts and their metal complexes possess more remarkable inhibition effects on hCA I and on hCA II for esterase activities than those of found for hydratase activities, and thus might be considered as possible candidate agents for in vivo therapeutic studies of glaucoma.

\section{Supplementary Information}

Supplementary data are available free of charge at http://jbcs.sbq.org.br as PDF file.

\section{Acknowledgments}

The authors acknowledge the support provided by Dumlupınar University Research Fund (grant No. 2012/16).

\section{References}

1. Supuran, C. T.; Casini, A.; Mastrolorenzo, A.; Scozzafava, A.; Mini-Rev. Med. Chem. 2004, 4, 625.
2. Scozzafava, A.; Owa, T.; Mastrolorenzo, A.; Supuran, C. T.; Curr. Med. Chem. 2003, 10, 925.

3. Choan, Z. H.; Hassan, M.; Khan, M. K.; Supuran, C. T.; J. Enzyme Inhib. Med. Chem. 2005, 20, 183.

4. Nielsen, P. M.; Fago, A.; J. Inorg. Biochem. 2015, 149, 6.

5. Alım, Z.; Kılınç, N.; İşgör, M. M.; Şengül, B.; Beydemir, Ş.; Chem. Biol. Drug Des. 2015, 86, 857.

6. Gocer, H.; Aslan, A.; Gülçin, İ.; Supuran, C. T.; J. Enzym. Inhib. Med. Chem., in press, DOI: 10.3109/14756366.2015.1043298.

7. Meleddu, R.; Maccioni, E.; Distinto, S.; Bianco, G.; Melis, C.; Alcaro, S.; Cottiglia, F.; Ceruso, M.; Supuran, C. T.; Bioorg. Med. Chem. Lett. 2015, 25, 3281.

8. Sugrue, M. F.; Prog. Retinal Eye Res. 2000, 19, 87.

9. Vilas, G.; Krishnan, D.; Loganathan, S. K.; Malhotra, D.; Liu, L.; Beggs, M. R.; Gena, P.; Calamita, G.; Jung, M.; Zimmermann, R.; Tamma, G.; Casey, J. R.; Alexander, R. T.; Mol. Biol. Cell 2015, 26, 1106.

10. Hitchings, R. A.; Eye 2009, 23, 1764.

11. Masini, E.; Carta, F.; Scozzafava, A.; Supuran, C. T.; Expert Opin. Ther. Pat. 2013, 23, 705.

12. Supuran, C. T.; Nat. Rev. Drug Discovery 2008, 7, 168.

13. Voss, K.; Falke, K.; Bernsdorf, A.; Grabow, N.; Kastner, C.; Sternberg, K.; Minrath, I.; Eickner, T.; Wree, A.; Schmitz, K. P.; Guthoff, R.; Witt, M.; Hovakimyan, M.; J. Controlled Release $\mathbf{2 0 1 5}, 214,1$.

14. Işı1k, S.; Vullo, D.; Durdagi, S.; Ekinci, D.; Şentürk, M.; Çetin, A.; Şentürk, E.; Supuran, C. T.; Bioorg. Med. Chem. Lett. 2015, 25, 5636.

15. Zhang, F.; Lin, Q. Y.; Zheng, X. L.; Zhang, L. L.; Yang, Q.; Gu, J. Y.; J. Fluoresc. 2012, 22, 1395.

16. Fuhrmann, H.; Brenner, S.; Arndt, P.; Kempe, R.; Inorg. Chem. 1996, 35, 6742.

17. Téllez, F.; López-Sandoval, H.; Castillo-Blum, S. E.; BarbaBehrens, N.; Arkivoc 2008, V, 245.

18. Yenikaya, C.; Büyükkıdan, N.; Sarı, M.; Keşli, R.; İlkimen, H.; Bülbül, M.; Büyükgüngör, O.; J. Coord. Chem. 2011, 64, 3353.

19. Yenikaya, C.; Poyraz, M.; Sarı, M.; Demirci, F.; İlkimen, H.; Büyükgüngör, O.; Polyhedron 2009, 28, 3526.

20. Zhou, F. L.; Ng, S. W.; Acta Crystallogr. 2011, 67, m792.

21. Mistri, S.; Zangrando, E.; Manna, S. C.; Inorg. Chim. Acta 2013, 405, 331.

22. Poddar, R. K.; Agarwala, U.; J. Inorg. Nucl. Chem. 1973, 35, 3769.

23. Raso, A. G.; Fiol, J. J.; Zafra, A. L.; Cabrero, A.; Mata, I.; Molins, E.; Polyhedron 1999, 18, 871.

24. Yenikaya, C.; Sarı, M.; İlkimen, H.; Bülbül, M.; Büyükgüngör, O.; Polyhedron 2011, 30, 535.

25. Büyükkıdan, N.; Yenikaya, C.; İlkimen, H.; Karahan, C.; Darcan, C.; Şahin, E.; Russ. J. Coord. Chem. 2013, 39, 24.

26. Yenikaya, C.; Sarı, M.; Bülbül, M.; İlkimen, H.; Çelik, H.; Büyükgüngör, O.; Bioorg. Med. Chem. 2010, 18, 930. 
27. Neelakantan, M. A.; Mariappan, S. S.; Dharmaraja, J.; Muthukumaran, K.; Acta Chim. Slov. 2010, 57, 198.

28. Shukla, S. N.; Gaur, P.; Kaur, H.; Prasad, M.; Mehrotra, R.; Srivastava, R. S.; J. Coord. Chem. 2008, 61, 441.

29. Bergmann, F.; Schapiro, D.; J. Org. Chem. 1942, 7, 419.

30. Sieron, L.; Acta Crystallogr. 2004, E60, m577.

31. Bukowska-Strzyzewska, M.; Skoweranda, J.; Tosik, A.; Acta Crystallogr. 1982, B38, 2904.

32. Rickli, E. E.; Ghazanfar, S. A.; Gibbson, B. H.; Edsall, J. T.; J. Biol. Chem. 1964, 239, 1065.
33. Bradford, M. M.; Anal. Biochem. 1976, 72, 248.

34. Laemmli, U. K.; Nature 1970, 227, 680.

35. Wilbur, K. M.; Anderson, N. G.; J. Biol. Chem. 1948, 176, 147.

36. Verpoorte, J. A.; Mehta, S.; Edsall, J. T.; J. Biol. Chem. 1967, $242,4221$.

37. Geary, W. J.; Coord. Chem. Rev. 1971, 7, 81.

Submitted: November 27, 2015 Published online: February 16, 2016 